JIPS, Vol. 1 No. 1

Halaman: 53 - 58

Desember 2020
Jurnal Inovasi Pembelajaran di Sekolah

DOI: https://doi.org/10.51874/jips.v1i01.7

ISSN 2774-9363 (Cetak)

ISSN 2774-9746 (Online)
JIPS

Jurnal Inovasi Pembelajaran di Sekolah

\title{
Keefektifan Model Pembelajaran The Power Of Two Terhadap Kemandirian dan Hasil Belajar Pada "Sub Tema 7.1. Keragaman Suku Bangsa dan Agama di Negeriku” Siswa Kelas IV SD Drajidan Kabupaten Boyolali
}

\author{
Icha Wahyu Prabawati ${ }^{1 *}$ \\ ${ }^{1}$ PGSD Universitas PGRI Semarang \\ *E-mail: ichawahyuprabawati15@gmail.com
}

\begin{abstract}
Abstrak
Penelitian ini dilatarbelakangi oleh guru hendaknya dapat memecahkan masalah pembelajaran untuk meningkatkan kemandirian belajar, yang dapat mendorong hasil belajar siswa dalam pembelajaran dan meningkatkan kreativitas guru. Guru dapat menggunakan salah satu model pembelajaran inovatif yaitu model pembelajaran The Power of Two. Penelitian ini dilaksanakan di dua SD Negeri kelas IV di SD Petarukan 1 sebagai kelas uji coba produk dengan jumlah responden 20 siswa dan sedangkan untuk kelas sampel adalah siswa kelas IV SD Negeri Drajidan Kabupaten Boyolali yang berjumlah 30. Berdasarkan hasil penelitian dapat disimpulkan bahwa hasil perhitungan uji t hasil belajar diperoleh thitung $=5,385$. Dari daftar distribusi $t$ dengan $\mathrm{dk}=\mathrm{n}-1=30-2=28$ diperoleh 1,701. Karena 5,385 > 1,701 maka Ho ditolak, sehingga dapat disimpulkan bahwa ada keefektifan model pembelajaran The Power of Two terhadap kemandirian dan hasil belajar siswa pada sub materi 7.1. "Keragaman Suku Bangsa dan Agama di Negeriku" siswa kelas IV SD Drajidan Kabupaten Boyolali tahun pelajaran 2019/2020. Saran dari peneliti adalah guru dalam melaksanakan penilaian memperhatikan model pembelajaran The Power of Two yang digunakan sehingga dapat meningkatkan kemandirian dan hasil belajar siswa.
\end{abstract}

Kata Kunci: the power of two, kemandirian, dan hasil belajar.

\begin{abstract}
This research is motivated by teachers should be able to solve learning problems to increase learning independence, which can encourage students' learning outcomes in learning and increase teacher creativity. Teachers can use one of the innovative learning models of The Power of Two learning model. This research was conducted in two elementary schools in grade IV at SD Petarukan 1 as a product trial class with a total of 20 respondents and while for the sample class were grade 4 students of SD Negeri Drajidan Boyolali which amounted to 30. Based on the results of the study can be concluded that the results of t test calculation of study results obtained thitung $=5,385$. From the distribution list $t$ with $d k=n-1=30-2=28$ obtained 1,701. Since 5,385 > 1,701, Ho was rejected, so it can be concluded that there is an effectiveness of The Power of Two learning model on student self-reliance and learning outcomes in subsection 7.1. "Ethnic and Religious Diversity in Negeriku" grade 4 students at Drajidan Elementary School, Boyolali, in the 2019/2020 school year. The advice from the researchers is that teachers in carrying out assessments pay attention to the learning model of The Power of Two used so as to increase the independence and learning outcomes of students.
\end{abstract}

Keywords:The Power of Two, Self-Reliance, and Learning Outcomes. 


\section{PENDAHULUAN}

Menurut Undang - Undang Sisdiknas No 20 Tahun 2003 pasal 1 disebutkan bahwa pendidikan adalah usaha sadar dan terencana untuk mewujudakan suasana belajar dan proses pembelajaran agar peserta didik secara aktif mengembangkan potensi dirinya untuk memiliki kekuatan spiritual keagamaan, pengendalian diri, kepribadian, kecerdasn akhlak mulia, serta keterampilan yang diperlukan dirinya, masyarakat, bangsa dan negara. Berdasarkan hasil observasi pada siswa kelas IV pada "Sub Tema 7.1. Keragaman Suku Bangsa dan Agama di Negeriku" masih ada siswa yang belum memahami materi. Data hasil belajar ditunjukkan dengan nilai terendah 61 dan nilai tertinggi 86, dengan rata-rata nilai kelas 70,8. Siswa yang mencapai KKM sebanyak 24 siswa atau $60 \%$ dari 40 siswa yang mencapai tuntas belajar. Permasalahan pertama pembelajaran masih belum optimal karena pembelajaran yang dilakukan guru menonton dan kurang kreatif, sehingga siswa kurang aktif, cepat merasa bosan dan penggunaan media dan sumber belajar yang masih kurang. Permasalahan kedua, proses pembelajaran masih berpusat pada guru sehingga suasana pembelajaran belum memberikan kesempatan kepada siswa untuk mengemukakan gagasan.

Kurikulum 2013 adalah kurikulum yang berlaku dalam Sistem Pendidikan di Indonesia. Kurikulum 2013 ini merupakan kurikulum tetap diterapkan oleh pemerintah untuk menggantikan Kurikulum 2006 yang biasanya dikenal dengan kurikulum KTSP (Kurikulum Tingkat Satuan Pendidikan), kurikulum 2013 bertujuan untuk mempersiapkan peserta didik agar memiliki kemampuan hidup sebagai pribadi dan warga negara yang beriman, produktif, kreatif, inovatif, dan afektif serta mampu berkontribusi pada kehidupan bermasyarakat, berbangsa, bernegara, dan peradaban dunia. Pembelajaran dalam kurikulum 2013 khususnya jenjang sekolah dasar dari kelas 1 sampai dengan kelas 6 menggunakan pendekatan tematik integratif. Mata pelajaran dalam kurikulum 2013 diintegrasikan menjadi pokok bahasan menggunakan tema dan subtema. Dengan demikian, siswa diharapkan mampu memahami materi secara menyeluruh. Pembelajaran pada sekolah dasar hendaklah memperhatikan berbagai aspek, karena anak pada usia SD memiliki karakteristik tersendiri yang harus dipahami oleh guru. Guru juga harus memahami perkembangan intelektual dan fungsi dari fisik peserta didik. Hal tersebut dimaksudkan agar tidak terjadi permasalahan dalam proses pembelajaran. Berdasarkan kurikulum 2013, guru sebagai subjek pembelajaran, hendaknya guru dapat meningkatkan kemampuan kognitif serta keaktifan belajar siswa. Salah satunya adalah penggunaan model pembelajaran yang lebih bervariasi. Model pembelajaran yang dipandang mampu memberi harapan dan memperbaiki situasi belajar di sini adalah model kooperatif. Salah satu model kooperatif tersebut adalah model pembelajaran The Power of Two. Guru hendaknya dapat memecahkan masalah pembelajaran untuk meningkatkan kemandirian belajar, yang dapat mendorong hasil belajar siswa dalam pembelajaran dan meningkatkan kreativitas guru. Guru dapat menggunakan salah satu model pembelajaran inovatif yaitu model pembelajaran The Power of Two. The Power of Twoartinya model 
pembelajaran yang menggabungkan kekuatan dua kepala. Menggabungkan dua kepala dalam hal ini adalah membentuk kelompok kecil, yaitu masing-masing siswa berpasangan. Kegiatan ini dilakukan agar munculnya suatu sinergi yakni dua kepala lebih baik dari satu (Silberman, 2006:173). Dengan menggunakan model pembelajaran The Power of Two ini, siswa dapat melakukan kerjasama sehingga dapat meningkatkan kemandirian belajar siswa. Model pembelajaran ini mendorong munculnya keuntungan dari sinergi itu, sebab dua orang tentu lebih baik daripada satu.

Dari ulasan latar belakang tersebut di atas maka peneliti mengkaji melalui penelitian tentang : Keefektifan Model Pembelajaran The Power of Two terhadap Kemandirian dan Hasil Belajar pada Sub Materi 7.1. "Keragaman Suku Bangsa dan Agama di Negeriku" Kelas IV SD Drajidan Kabupaten Boyolali.

Adapun rumusan masalah tersebut dapat dirinci sebagai berikut:

1. Bagaimanakahkemandirian belajar pada sub materi 7.1. "Keragaman Suku Bangsa dan Agama di Negeriku" siswa kelas IV SD Drajidan Kabupaten Boyolali sebelum dan sesudah menggunakanmodel pembelajaran The Power of Two?

2. Bagaimanakah hasil belajar pada sub materi 7.1. "Keragaman Suku Bangsa dan Agama di Negeriku" siswa kelas IV SD Drajidan Kabupaten Boyolali sebelum dan sesudah menggunakan model pembelajaran The Power of Two ?

\section{METODE PENELITIAN}

Penelitian ini dilaksanakan pada semester II tahun ajaran 2019/2020 pada saat materi sub materi 7.1. "Keragaman Suku Bangsa dan Agama di Negeriku” di kelas IV SD Drajidan Boyolali.

\section{HASIL DAN PEMBAHASAN}

Penelitian ini bertujuan untuk mengetahui keefektifan model pembelajaran The Power of Two terhadap kemandirian dan hasil belajar siswa pada sub materi 7.1. "Keragaman Suku Bangsa dan Agama di Negeriku" siswa kelas IV SD Drajidan Kabupaten Boyolali tahun pelajaran 2019/2020. Hasil kemandirian belajar pada kelas pre test diperoleh indikator percaya diri dalam belajar yaitu 76,67\%, mampu belajar mandiri diperoleh skor $60 \%$, mampu mengambil keputusan yaitu $80 \%$, mampu mengatur waktu belajar sebesar 53,33\%, dan bertanggung jawab dalam belajar sebesar $60 \%$. Kemandirian belajar siswa pada kelas pre test diperoleh diperoleh rata-rata sebesar 66 dengan kriteria cukup.

Kemandirian belajar pada kelas post test diperoleh indikator percaya diri dalam belajar yaitu $83,33 \%$, mampu belajar mandiri diperoleh skor 70\%, mampu mengambil keputusan yaitu 80\%, mampu mengatur waktu belajar sebesar 66,67\%, dan bertanggung jawab dalam belajar sebesar 73,33\%. Kemandirain belajar siswa pada kelas post test diperoleh diperoleh rata-rata sebesar 74,67 dengan kriteria baik. Berdasarkan nilai pre test diperoleh rata-rata nilai 73,370 dengan nilai tengah 75 dan modus 75. Dari nilai ketuntasan, diperoleh KKM dari sub materi 7.1. "Keragaman Suku Bangsa dan 
Agama di Negeriku" siswa kelas IV SD Drajidan Kabupaten Boyolali tahun pelajaran diperoleh nilai 75. Hasil data siswa yang mengalami ketuntasan belajar terdapat 35 siswa, dan 11 siswa yang tidak tuntas belajar. Berdasarkan nilai pre test diperoleh rata-rata nilai 77,600 dengan nilai tengah 74 dan modus 76. Dari nilai ketuntasan, diperoleh KKM dari diperoleh nilai 75. Hasil data siswa yang mengalami ketuntasan belajar terdapat 35 siswa, dan 11 siswa yang tidak tuntas belajar.

Nilai post test diperoleh diperoleh rata-rata nilai 78,804 dengan nilai tengah 75 dan modus 75 . Dari nilai ketuntasan, diperoleh KKM dari SD Drajidan Kabupaten Boyolali Tahun Pelajaran 2019/2020 adalah 75. Hasil data siswa yang mengalami ketuntasan belajar terdapat 27, dan 3 siswa yang tidak tuntas belajar. Pada nilai pre test dengan nilai rata- rata hasil belajar sebesar 77,600. Sedangkan pada nilai post test dengan nilai rata - rata hasil belajar sebesar 83,600. Peningkatan nilai kognitif siswa ini sesuai dengan pendapat Bloom (2017) perilaku-perilaku yang menekankan aspek intelektual, seperti pengetahuan, pengertian, dan keterampilan berpikir. Pengetahuan yang berupa hasil belajar siswa pada pada sub materi 7.1. "Keragaman Suku Bangsa dan Agama di Negeriku" siswa kelas IV SD Drajidan Kabupaten Boyolali tahun pelajaran 2019/2020. Berdasarkan hasil perhitungan uji $\mathrm{t}$ hasil belajar diperoleh $\mathrm{t}_{\text {hitung }}=5,385$. Dari daftar distribusi $\mathrm{t}$ dengan $\mathrm{dk}=\mathrm{n}-1=30-2=28$ diperoleh 1,701. Karena 5,385 > 1,701 maka Ho ditolak, sehingga dapat disimpulkan bahwa ada keefektifan model pembelajaran The Power of Two terhadap kemandirian dan hasil belajar siswa pada sub materi 7.1. "Keragaman Suku Bangsa dan Agama di Negeriku" siswa kelas IV SD Drajidan Kabupaten Boyolali tahun pelajaran 2019/2020.

Penerapan model pembelajaran ini dapat meningkatkan hasil belajar siswa. Hal ini dikarenakan model pembelajaran The Power of Two, yang memiliki kelebihan yaitu suatu model pembelajaran yang berusaha meletakkan dasar dan mengembangkan cara berpikir ilmiah, yang menempatkan siswa lebih banyak belajar sendiri, mengembangkan kekreatifan dalam memecahkan masalah. Siswa mempelajari materi pelajaran secara kelompok dan menghubungkannya dengan kegiatan yang berlangsung. Disini guru hanya berperan sebagai fasilitator. Meningkatkan aktivitas belajar siswa, menambah kepercayaan diri dalam diri siswa.

Hal ini sesuai dengan pendapat Huda (2015) kelebihan pembelajaran dengan menggunakan model The Power of Two adalah model pembelajaran kooperatif dengan diawali dengan mengajukan pertanyaan. Diharapkan pertanyaan yang dikembangkan adalah pertanyaan yang membutuhkan pemikiran kritis. Pembelajaran dengan model The Power of Two ini mengajarkan siswa untuk dapat mandiri dan percaya diri dalam pengembangan dirinya sebagai manusia yang mempunyai sifat ingin tahu, aktif, kreatif, guru mampu meningkatkan sifat tersebut yang dihubungkan dengan permasalahan yang sering dihadapi oleh siswa, sehingga siswa memiliki kemauan untuk melakukan percobaan atau pengamatan untuk mengetahui jawabannya. Model The Power of Two ini juga menciptakan suasana yang menyenangkan, sehingga sebagian besar siswa aktif selama proses pembelajaran. 


\section{PENUTUP}

Berdasarkan hasil penelitian dapat disimpulkan bahwa hasil perhitungan uji t hasil belajar diperoleh $\mathrm{t}_{\text {hitung }}=5,385$. Dari daftar distribusi $\mathrm{t}$ dengan $\mathrm{dk}=\mathrm{n}-1=30-2=28$ diperoleh 1,701. Karena 5,385 > 1,701 maka Ho ditolak, sehingga dapat disimpulkan bahwa ada keefektifan model pembelajaran The Power of Two terhadap kemandirian dan hasil belajar siswa pada sub materi 7.1. "Keragaman Suku Bangsa dan Agama di Negeriku" siswa kelas IV SD Drajidan Kabupaten Boyolali tahun pelajaran 2018/2019.

\section{SARAN}

1. Guru dalam melaksanakan penilaian memperhatikan model pembelajaran The Power of Two yang digunakan sehingga dapat meningkatkan kemandirian dan hasil belajar siswa.

2. Guru harus memperhatikan model pembelajaran yang akan ditetapkan dalam setiap pencapaian indikator.

3. Guru dapat selalu mengadakan praktikum dengan pemanfaatan model The Power of Two sehingga siswa dapat aktif di dalam kelas.

\section{DAFTAR PUSTAKA}

Ali, Muhammad dan Asrori. 2009. Psikologi Remaja. Bandung: Alfabeta.

Anita Lie. 2004. Cooperative Learning. Jakarta: Grasindo.

Agus Suprijono. 2009. Cooperative Learning. Yogyakarta : Pustaka Belajar.

Arikunto, S. 2002. Prosedur Penelitian Suatu Pendekatan Praktek. Jakarta: PT Rineka Cipta.

Arikunto, S. 2006. Prosedur Penelitian Suatu Pendekatan Praktek. Jakarta: PT Rineka Cipta.

Badarudin. 2011. Keterampilan Dasar Mengajar. (http://ayahhalby.wordpress.com)

Cain dan Evans. 2010. Hakekat IPA. http:/leprints.uny.ac.id.

Dahar, Ratna Willis. 2006. Teori-teori Belajar dan Pembelajaran. Jakarta: Erlangga.

Depdiknas. 2004. Peningkatan Kualitas Pembelajaran. Jakarta: Depdiknas.

Dimyati dan Mudjiono. 2009. Belajar dan Pembelajaran. Jakarta: PT Rineka Cipta.

Djamarah, S.B dan Zain, A. 2006. Strategi Belajar Mengajar. Jakarta: PT Rineka Cipta.

Donald A, Joseph dan Derosa, dan Aburscato. 2010. Hakekat IPA. http://eprints.uny.ac.id.

Hamalik, Oemar. 2009. Psikologi Belajar dan Mengajar. Bandung: Sinar Baru Algensindo.

Muhammad Thobroni dan Arif Mustofa. 2011. Belajar dan Pembelajaran Pengembangan Wacana dan Praktik Pembelajaran dalam Pembangunan Nasional.

Silberman, M. (2006). Active Learning: 101 Strategi Pembelajaran Aktif. Bandung : Nusamedia.

Sudjana, N., 2009. Dasar-dasar Proses Belajar Mengajar. Bandung : Penerbit Sinar Baru Algesindo. 
Suharso dan Retnaningsih. 2011. Kamus Besar Bahasa Indonesia. Jakarta: Rineka Cipta.

Sudjana. 2005. Matode Statistika. Bandung: Tarsito.

Sugiyono. Statistik Non Parametris untuk Penelitian. Bandung : CV. Alfabeta.

Syah, Muhibbin. 2014. Psikologi Belajar. Jakarta: Rajawali Press.

Trianto. 2011. Model-model Pembelajaran Inovatif Berorientasi Konstruktivistik. Surabaya: Prestasi Pustaka Publisher.

Wina, S., 2008. Pembelajaran dalam Implementasi Kurikulum Berbasis Kompetensi. Jakarta: Kencana Prenada Media Group. 